\title{
Pacientu autonomijas krimināltiesiskā aizsardzība Latvijā: vai nepieciešama jauna norma Krimināllikumā?
}

\author{
Dr. iur. Aldis Lieljuksis \\ ORCID: 0000-0003-2610-6690 \\ Rīgas Stradiña universitāte, Juridiskā fakultāte, Latvija \\ Aldis.Lieljuksis@rsu.lv
}

\section{Kopsavilkums}

Raksts ir turpinājums problēmas izpētei par pacienta tiesību aizsardzību krimināltiesībās. Darbā izpētītas Krimināllikuma normas, kurās paredzēta ārstniecības personu atbildība par ārstniecību bez pacienta piekrišanas. Tikai Krimināllikuma 135. pantā expresis verbis paredzēta atbildība par aborta izdarǐšanu pret grūtnieces gribu. Citos gadījumos atbildība var iestāties, vienīgi konstatējot ārstniecības procesā prettiesiski nodarìtas vismaz vidēji smaga miesas bojājuma sekas. Tiesu nolēmumos jautājums par informētās piekrišanas esamību netiek skarts, tādēl faktiskā situācija ir neskaidra. Jāatzīmē, ka tiesiskais regulējums ir atšķirīgs no tādām Eiropas valstīm kā Polija, Portugāle un Lihtenšteina, kur paredzēta kriminālatbildība ne tikai par pacientam nodarìtu kaitējumu veselības aprūpē, bet arī par to, ja ārstniecība veikta bez pacienta piekrišanas situācijās, kad tā bija nepieciešama, jo tika prettiesiski aizskartas pamattiesības. Autora ieskatā, pētnieciskais darbs ir jāturpina, apzinot citu valstu pieredzi un faktisko situāciju pirms priekšlikumu izvirzišanas kriminālatbildības paredzēšanai Krimināllikumā.

Atslēgvārdi: Satversme, Krimināllikums, informētā piekrišana.

\section{levads}

Pasaules Veselības organizācijas Konstitūcijā veselība definēta kā pilnīga fiziska, garīga un sociāla labklājỉba, ne tikai slimības vai nespējas trūkums [24]. Katrs vēlas būt vesels, taču nav garantijas, ka cilvēks neslimos un nenonāks pacienta statusā, savukārt, lai neslimotu, ir jāvēršas pie ārstniecības personas, lai saṇemtu profesionālu palīdzību. Pacienta tiesības iedala sociālajās tiesībās, kas saistìtas ar pacienta kā sabiedrības locekḷa tiesībām un valsts pienākumu pret saviem iedzīvotājiem, un individuālajās tiesībās: 
personas tiesībās uz ārstniecību, tiesībās uz informāciju, informētu piekrišanu, konfidencialitātes un privātuma aizsardzību [21]. Pacienta tiesības uz informēto piekrišanu pirms ārstniecības uzsākšanas ir pacienta individuālās tiesîbas un nodrošina personas autonomiju un integritāti kā neatṇemamu cilvēktiesību vērtību, kas ierobežojama vienīgi likumā paredzētos gadījumos.

Latvijas Republikas Satversme ir Latvijas pamatlikums jeb konstitūcija. Vairākās Satversmes normās ir ielasāmas personas tiesības uz informēto piekrišanu. Pacienta tiesības uz brīvību un neaizskaramību paredzētas Satversmes 94. pantā, un personas nogādāšana psihiatriskajā klīnikā bez likumā paredzēta pamata ir personas tiesību uz brīvību aizskārums, savukārt piespiedu terapija un tās maiṇa, kas veikta neatbilstoši Ārstniecības likuma XI nodaḷā ietvertajam regulējumam, ir tiesību uz neaizskaramību pārkāpums. Satversmes 96. pantā paredzētās tiesības uz privātās dzìves neaizskaramību ietver tiesības uz personas autonomiju un brīvu izvēli, tādē ārstniecība bez informētās piekrišanas personām, kuru brīva izvēle nav ierobežota ar likumu, ir šo tiesību pārkāpums.

Ārstniecỉba bez informētās piekrišanas dažādos faktiskajos apstākḷos var būt saistìta arī ar tiesību aizskārumu, kas paredzētas Satversmes 93. pantā, kur teikts, ka ikviena tiesības uz dzīvību aizsargā likums, vai 111. pantā, kur teikts, ka valsts aizsargā cilvēka veselību un garantē ikvienam medicīniskās palīdzības minimumu.

\section{Pacientu tiesību aizsardzība Latvijas tiesiskajā sistēmā}

Atbilstoši Satversmes 89. pantam valsts pozitīvais pienākums ir aizsargāt personas pamattiesības, pieņemot attiecīgas normas, taču tas, vai atbildībai par ikvienu iepriekš minēto tiesību pārkāpumu jābūt paredzētai vienīgi Krimināllikumā, ir pēc būtības jārisina krimināltiesiskās politikas ietvarā. Pēdējais šāds apjomīgs kriminālsoda politikas dokuments Latvijā tika pieņemts, Ministru kabinetam 2009. gadā apstiprinot Kriminālsodu politikas koncepciju, kuras mērḳis bija "nodrošināt efektīvu valsts reakciju uz noziedzīgiem nodarījumiem, nodrošināt atbilstību starp valsts vārdā piemērojamo represiju un valsts un indivīdu interesēm, sekmēt personu tiesisku uzvedību un noziedzīgu nodarïjumu novēršanu" [12]. Savukārt profesora A. Vilka ieskatā "krimināltiesiskā politikā primārās ir atsevišķ cilvēka intereses un tiesības. To konsekventa ievērošana ir ikvienas stabilas un harmoniski attīstîtas valsts pamatā" [23].

Šādai prioritāšu secībai var piekrist, turklāt arī Krimināllikuma 7. pantā, paredzot noziedzīgu nodarījumu klasifikāciju, teikts, ka iedalījuma pamatā ir personas vai sabiedrības interešu apdraudējuma raksturs un kaitīgums. Lìdz ar to daḷā krimināltiesību normu, kas saistītas ar ārstniecību, paredzēta kriminālatbildība neatkarīgi no sekām, piemēram, par aborta neatḷautu izdarīšanu pret grūtnieces gribu. Savukārt atbildība ārstniecības personai par pienākumu nepildīšanu vai nolaidīgu pildīšanu iestājas, ja sekas ir vismaz vidēji smagi miesas bojājumi, kas nodarīti aiz neuzmanības. Jebkurā gadījumā Latvijā personai par ārstniecības procesā prettiesiski nodarīto kaitējumu veselībai vai 
Aldis Lieljuksis. Pacientu autonomijas krimināltiesiskā aizsardzība Latvijā:

vai nepieciešama jauna norma Krimināllikumā?

dzīvībai ir tiesības saņemt atlīdzinājumu civiltiesiskā kārtībā. Arī administratīvā procesa kārtībā persona var vērsties tiesā, ja vinu neapmierina Veselības inspekcijas aprēḳinātais atlīdzības apmērs no Ārstniecības riska fonda. Atbilstoši Pacientu tiesību likuma 16. panta otrajai dal̦ai atlīdzība par pacienta dzīvībai vai veselībai nodarìto kaitējumu (arī morālo) nevar pārsniegt 142290 eiro, savukārt pacienta izdevumi atlīdzināmi radīto izdevumu apmērā, bet ne vairāk kā 28460 eiro.

Krimināllikuma XIV nodạ̄ā, kurā ietverta atbildība par nodarïjumiem par pamattiesību un pamatbrīīibu aizskārumu, nav speciālas normas, kas paredzētu atbildību par ārstniecību bez informētās piekrišanas. Savukārt Krimināllikuma XIII nodaḷā, kurā ietverti nodarījumi pret personas veselību, un Krimināllikuma XV nodalāaa, kurā ietverti nodarījumi pret personas brīvību, godu un cieṇu, ir paredzētas normas, kas saistāmas ar informētās piekrišanas aspektu [4].

Kopumā jāatzīst, ka līdz šim tiesu nolēmumos krimināllietās tikai vienā lietā ir apskatīts jautājums par informēto piekrišanu un arī tad kontekstā ar personas neinformēšanu par rīcību pēc izrakstǐšanas no stacionāra, kur tika veikta ḳirurğiska iejaukšanās. Tika pārkāptas Pacientu tiesību likuma 4. panta 6. daḷā paredzētās tiesības uz informāciju pēc ārstniecības vai ārstniecības posma pabeigšanas [25]. Lìdztekus tam administratīvajā procesā, izskatot pacienta sūdzību, informētās piekrišanas aspekts tiek vērtēts, apzinot un nosakot kompensācijas par nodarìto kaitējumu apmēru.

Latvijas Republikas Augstākā tiesa ir izdevusi divus tiesu prakses apkopojumus par morālā kaitējuma atlīdzināšanu civillietās - 2014. gadā un 2016. gadā. Civillietās, izskatot prasību par pacientam nodarīto morālo kaitējumu ārstniecības procesā, informētās piekrišanas aspekts tiek pieminēts vien dažos spriedumus, turklāt detalizēts vērtējums netiek sniegts [26]. Jautājumu par pārmērīgu ietekmi uz pacienta gribu kā prettiesisku rīcību, tās kritērijus un civiltiesiskās sekas risina tiesību zinātniece L. Mazure, piedāvājot nākotnē papildināt Pacientu tiesību likumu ar regulējumu, atzīstot pacienta gribas izteikumu par spēkā neesošu, ja tas izteikts pārmērīgā ietekmē [18]. Nepārprotami šis jautājums ir saistīts ne tikai ar civiltiesisko aspektu, bet arī ar Krimināllikuma 135. panta 4. dal̦as regulējumu par aborta neaț̣autu izdarīšanu pret grūtnieces gribu, kur subjekts var būt arī ārstniecības persona, kā arī Krimināllikuma 136. panta regulējumu, kas paredz kriminālatbildību par grūtnieces piespiešanu izdarīt abortu. Lìdz ar to, pien,emot šādu regulējumu, jārisina arī jautājums par atbildības veidu nošķiršanu.

Krimināllikuma normas, kur paredzēta kriminālatbildība par prettiesisku ārstniecību, ir blanketas, tādēl normu dispozịcijas ir nesaraujami saistìtas ar citiem tiesību aktiem - likumiem un tiem pakārtotiem Ministru kabineta noteikumiem. Ārstniecība ir definēta Ārstniecības likuma 1. panta 1. punktā: tā ir profesionāla un individuāla slimību profilakse, diagnostika un ārstēšana, medicīniskā rehabilitācija un pacientu aprūpe. Informētās piekrišanas sakarā svarīgākie tiesību akti ir Pacientu tiesību likums (Latvijā stājās spēkā 2010. gada 1. martā), kā arī attiecībā uz pacientiem, kuriem nepieciešama psihiatriskā palīdzība, - arī Ārstniecības likuma (stājās spēkā 1997. gada 1. oktobrī) XI nodaḷa "Psihiskās slimības". Ārstniecības likumā ir definēta "psihiatriskā palīdzība 
Aldis Lieljuksis. Pacientu autonomijas krimināltiesiskā aizsardzība Latvijā:

vai nepieciešama jauna norma Krimināllikumā?

bez pacienta piekrišanas": stacionāra diagnostika, ārstēšana, rehabilitācija un aprūpe personai ar garīgās veselības traucējumiem bez šìs personas piekrišanas.

Paralēli ārstniecības procesam pacients var iesaistīties vai arī var tikt iesaistìts (normatīvajos aktos noteiktos gadījumos, kad pats nav spējīgs pieṇemt lēmumu) klīniskajos pētījumos. Šādos gadījumos tiek piemērotas Farmācijas likumā un tam pakārtotajos Ministru kabineta noteikumos ietvertās normas, Ārstniecības likuma, kā arī Pacientu tiesību likuma normas. Informētās piekrišanas sakarā Pacientu tiesību likuma 12. panta otrajā dạ̣ā paredzēts, ka atteikšanās piedalīties vai piedalīšanās pārtraukšana pētījumā nedrīkst nelabvēlīgi ietekmēt ārstniecības personu attieksmi pret pacienta turpmāko ārstniecību.

Būtisks tiesiskais regulējums attiecībā uz informēto piekrišanu ārstniecībai ir ietverts Pacientu tiesību likuma 4. panta trešajā dạ̦ā, kas regulē pacienta tiesības uz informācijas saṇemšanu par savu veselības stāvokli, tostarp slimības diagnozi, ārstēšanas, izmeklēšanas un rehabilitācijas plānu, prognozi un sekām, arī slimības radītajiem funkcionēšanas ierobežojumiem, profilakses iespējām, kā arī tiesības pēc ārstniecības gaitā veiktas izmeklēšanas un ḳirurğiskās vai cita veida invazīvās iejaukšanās saṇemt informāciju par ārstniecības rezultātiem, par iepriekš neparedzētu iznākumu un tā iemesliem [2].

Savukārt likuma 6. pantā definēta informētās piekrišanas būtība, izpausme gan mutiski, gan arī - pēc pacienta vēlmes - rakstiski, dokumenta saturs, pacienta tiesības, kā arī ārsta rīcība, pacientam atsakoties no ārstniecības pirms tās uzsākšanas, tās laikā vai no izraudzītas metodes, kā arī atsakoties pacientam rakstiski to apliecināt. Savukārt Pacientu tiesību likuma 7. pantā paredzēti apstākḷi un regulētas attiecības, kad pacienta vietā lēmumu par ārstniecību vai atteikšanos no tās pien,em citas personas - tuvākie radinieki vai ārstu konsīlijs, ja radinieki nespēj vienoties. Normas 7. dạā regulēta rīcība gadījumos, kad novilcināšanās apdraud pacienta dzīvību un nav iespējams saṇemt paša pacienta vai personas, kas pārstāv pacientu, piekrišanu. Tādā gadỉjumā ārstēšanas plānu apstiprina un lēmumu pieņem ārstu konsīlijs, izņemot gadỉjumus, kad sniedzama pirmā vai neatliekamā medicīniskā palīdzība. Ārkārtīgi svarīga ir Pacientu tiesību likuma 7. panta devītās daḷas norma, kurā paredzēta situācija, kad ārstniecības personai bez pacienta piekrišanas ir tiesības veikt ārstniecību: ḳirurğiskās vai citu veidu invazīvās iejaukšanās laikā ārstējošajam ārstam bez pacienta piekrišanas ir tiesības veikt iepriekš neplānotu ārstēšanu, ja pacientam sniedzama neatliekamā medicīniskā palīdzība vai ja neveiktās ārstēšanas dēl radīsies nesalīdzināmi lielāks kaitējums viṇa veselībai.

Attiecībā uz nepilngadīgiem pacientiem jāatzīmē, ka atbilstoši Pacientu tiesību likuma 13. pantam nepilngadīga pacienta līdz 14 gadu vecumam ārstniecība piel̦aujama, ja viṇa likumīgais pārstāvis par to ir informēts un devis savu piekrišanu. Pacientam ir tiesības tikt uzklausitam un atbilstoši vecumam un briedumam piedalīties lēmumu pien,emšanā. Savukārt no 14 gadu vecuma pacienta ārstniecíba piel̦aujama, ja saṇemta viṇa piekrišana. Ja 14 gadu vecumu sasniegusi persona atsakās piekrist ārstniecībai, savukārt ārsts uzskata, ka ārstniecība ir pacienta interesēs, piekrišanu dod nepilngadīgā pacienta likumīgais pārstāvis. Izṇēmums ir jau iepriekš minētais 7. panta septītās daḷas 
Aldis Lieljuksis. Pacientu autonomijas krimināltiesiskā aizsardzība Latvijā:

vai nepieciešama jauna norma Krimināllikumā?

regulējums. Jāuzsver, ka, pacientam iesaistoties klīniskā pētījumā, informētā piekrišana ir noformējama tikai rakstiski.

\section{Noziedzīgo nodarījumu statistiskie rādītāji}

Noziedzīgu nodarījumu, kas saistīti ar ārstniecības personu prettiesisku rīcību, tradicionāli ir maz, vai arī gadiem ilgi nav konstatēts neviens noziedzīgs nodarījums, piemēram, Krimināllikuma 135. pants - aborta neatḷauta izdarī̌ana, Krimināllikuma 136. pants - piespiešana izdarìt abortu. Krimināllikuma 138. pants "Ārstniecības personas profesionālo pienākumu nepienācīga pildī̌̌ana” 2019. gadā piemērots, uzsākot sešus kriminālprocesus (trīs pēc Krimināllikuma 138. panta pirmās dal̦as un trīs pēc otrās daḷas). 2018. gadā reg̣istrēti trīs noziedzīgi nodarījumi, uz kuriem attiecināms Krimināllikuma 138. pants (viens pēc normas pirmās dal̦as un divi pēc normas otrās daḷas).

\section{Vēsturisks ieskats pacientu tiesību aizsardzībā krimināltiesībās Latvijā}

Šajā apakšnodaḷā tiks apskatīta ārstniecības personu atbildība Sodu likumā, kur jau starpkaru periodā bija paredzēta kriminālatbildība par ārstniecību bez piekrišanas. Šodienas apstākḷos, kad informētā piekrišana galvenokārt saistīta ar atsaucēm uz pēckara laikā pieņemtiem starptautiskajiem tiesību aktiem, kā arī Latvijas Republikas Satversmes VIII nodą̧u "Cilvēka pamattiesības" normām, Eiropas Cilvēktiesību tiesas nolēmumiem un Latvijas Republikas Augstākās tiesas Senāta spriedumiem, var rasties aplams priekšstats, ka prasība pēc pacienta informētās piekrišanas un atbildība par tās neesamību apstākḷ̆os, kad tai bija jābūt, ir radusies mūsdienās un tikai tagad attīstās.

Šādu priekštatu par informētās piekrišanas kā indivīda autonomijas izpausmi un vienu no ētikas pamatprincipa vienīgi mūsdienīgo izcelsmi kliedē modernizētais Hipokrāta (ap 460.-370. gadu p. m. è.) zvērests, ko, absolvējot augstskolu, nodod Rīgas Stradiṇa universitātes studenti, nākamie ārsti, un tajā ietvertie vārdi "es respektēšu sava pacienta autonomiju un cieņu". Pētot pacienta gribas attīstību cauri gadsimtiem, savā promocijas darbā informētās piekrišanas aspektā L. Mazure secina, ka "Hipokrāta zvērests ir vērtējams kā "mācekḷa un viṇa skolotāja sadarbības līgums", kur nodalāmas divas daḷas: 1) mācekḷa apṇemšanās savā darbībā pret savu skolotāju; 2) ārsta ètikas pamatprincipi, arī attiecībā pret pacientu" [19].

Informētā piekrišana laika gaitā ieguvusi ne tikai ētisku, bet arī krimināltiesisku dimensiju, un šodien "informētā piekrišana ir uzskatāma gan par medicīnas tiesību, gan arī medicīnas ētikas un bioētikas stūrakmeni” [22]. Informētā piekrišana kā cilvēka autonomijas aizsarglīdzeklis un tiesiskas ārstniecības elements gandrīz gadsimtu ir cieši saistīta ar krimināltiesībām Latvijā. Starpkaru periodā pieñemtā Latvijas Sodu likuma [7] 218. pantā ir paredzēta atbildība par ārstēšanu bez tiesībām to darīt, kā arī ārstēšanu ar indīgām un stipra iespaida vielām vai stipra iespaida līdzekḷiem vai par amatveidīgi 
mantkārīgā nolūkā nodarbošanos ar dzemdināšanas palīdzības sniegšanu. Savukārt normas otrajā dạā paredzēta atbildība ārstam, kas ārstējis slimnieku bez viṇa vai, ja viṇš ir nepieskaitīgs, bez vecāku vai to aizvietotāju personu piekrišanas, izṇemot likumā vai saistošos noteikumos paredzētos piespiedu ārstēšanas gadījumos, vai ja ārsta iejaukšanās notikusi aiz līdzcietības pret slimnieku. Normas trešajā daḷa subjekti ir feldšeri, sanitāri, žēlsirdīgās māsas, slimnieku kopējas un vecmātes, kas bez ievērojama iemesla pārkāpuši viṇu darbībai ar likumu vai noteikumiem noliktās robežas. Paredzētais sods - arests uz laiku, ne ilgāk par trim mēnešiem, vai naudas sods, ne augstāk par trīs simti latu. Savukārt Sodu likuma 219. pantā paredzēta atbildība ārstam vai vecmātei, kas nolaidīgi vai sava aroda nezināšanas dēl nemākulīgi ārstējuši, ja par nodarīto nedraud bargāks sods. Sods - arests uz laiku, ne ilgāk par trim mēnešiem, vai naudas sods, ne augstāk par trīs simti latu [7].

1939. gadā izdotajā profesora P. Minca grāmatā "Krimināltiesību kurss. Sevišḳā daļa", kas atkārtoti izdota 2005.gadā, autors norāda, ka "sodāmība pēc 218. panta pati par sevi atkrìt t. s. "nepieciešamības" apstākḷos. Pacienta nepamatotas sūdzības par šķietami nolaidīgu ārstēšanu novērš Kriminālprocesa likumu 1175. panta nosacījums, kas pirms ārsta saukšanas pie kriminālatbildības par ārstniecības likuma pārkāpšanu uzdod pieprasìt atsauksmi no ārstu pārraudzības iestādes (sava veida "administratīva garantija”!)” [20]. Jāpiebilst, ka Sodu likuma 45. pantā, kas pielīdzināms Krimināllikuma 32. pantam "Galēja nepieciešamība", pirmajā rindkopā attiecībā uz izskatāmo jautājumu paredzēts, ka "nav uzskatāms par noziedzīgu nodarījumu, kas izdarìts, lai glābtu savu vai citas personas dzīvību no briesmām, kuras tajā pašā laikā nav bijušas novēršamas ar citu līdzekli" [7].

Kā redzams, krimināltiesiskais regulējums jau pirmskara Latvijā paredzēja kriminālsodu vienā normā par ārstniecību bez attiecīgām tiesībām un bez piekrišanas, kā arī citā normā - atbildību par nolaidīgu ārstniecību. Šādā veidā vismaz dạ̣ēji tiesiskais regulējums ir ietverts arī Krimināllikuma normās, paredzot atbildību Krimināllikuma 137. pantā "Neatḷauta ārstniecība" un Krimināllikuma 138. pantā "Ārstniecības personu profesionālo pienākumu nepildīšana". Lai gan Krimināllikumā tika saglabāta zināma Sodu likuma pēctecība, par ko raksta profesors U. Krastiņš, atskatoties uz Krimināllikuma tapšanu, norādot, ka "šajā jaunajā procesā bija ievērotas Latvijas krimināltiesību teorētiskās iestrādes un netika aizmirstas krimināltiesību tradīcijas, kas veidojās neatkarīgajā Latvijā pagājuša gadsimta divdesmitajos un trīsdesmitajos gados, un tajā pašā laikā tika n,emta vērā arī ārvalstu pieredze krimināltiesību veidošanā" [16]. Taču iepriekš minētās normas, kas paredzēja kriminālatbildību par ārstēšanu bez piekrišanas, netika pārṇemtas, lai gan informētās piekrišanas koncepts un prasība saṇemt pacienta piekrišanu bija paredzēta gadu agrāk par Krimināllikumu - 1997. gadā pieņemtā Ārstniecības likuma 41. pantā. Turpmāk tiks izskatīts Krimināllikuma un Kriminālprocesa likuma normās paredzētais regulējums, kas saistìts ar ārstniecību un informēto piekrišanu secīgā kārtībā. 
Aldis Lieljuksis. Pacientu autonomijas krimināltiesiskā aizsardzība Latvijā:

vai nepieciešama jauna norma Krimināllikumā?

\section{Kriminālatbildība}

Krimināllikuma Vispārīgā dal̦a. Vispārīgās dal̦as III nodaḷā "Apstākḷi, kas izslēdz kriminālatbildību" ietvertas kriminālatbildību izslēdzošas normas: nepieciešamā aizstāvēšanās, šḳietamā aizstāvēšanās, aizturēšana, radot personai kaitējumu, galējā nepieciešamība, attaisnots profesionālais risks, noziedzīgas pavēles un noziedzīga rīkojuma nepildīšana.

Krimināllikuma 33. pantā ietvertā norma "Attaisnots profesionālais risks" paredz:

“(1) Kriminālatbildība neiestājas par kaitējumu, kas nodarīts ar profesionālu darbību, kurai ir noziedzīga nodarījuma sastāva pazīmes, ja šì darbība izdarīta, lai sasniegtu sociāli derīgu mērḳi, kuru nebija iespējams sasniegt citādā veidā. Ar šo darbību saistītais profesionālais risks uzskatāms par attaisnojamu, ja persona, kas piel̦āvusi risku, ir darījusi visu, lai novērstu kaitējumu tiesiski aizsargātām interesēm.

(2) Risks nav atzīstams par attaisnotu, ja tas ir apzināti saistīts ar vairāku personu dzīiības apdraudējumu vai ar draudiem izraisīt ekologisku katastrofu vai sabiedrisku postu."

Šì norma ir cieši saistìta ne tikai ar ārstniecību un tai piemītošo risku, bet arī pacienta tiesību aizsardzību, tostarp attiecībā uz piedalǐšanos klīniskajos pētỉjumos. Atbilstoši Pacientu tiesību likuma 11. panta pirmajai daḷai pacientu iesaista klīniskajā pētījumā, kas apstiprināts atbilstoši kārtībai, kāda noteikta normatīvajos aktos par klīniskajiem pētījumiem, ja ir saṇemta viņa rakstveida informētā piekrišana un klīnisko pētījumu veic, vienlaikus pastāvot šādiem nosacījumiem:

1) paredzamais risks ir izvērtēts attiecībā uz prognozējamo pacienta, kā arī citu esošo vai nākamo pacientu ieguvumu;

2) nepastāv alternatīva, ka salīdzināmu efektu varētu iegūt citādā veidā;

3) ārstnieciskais ieguvums, kā arī ieguvums sabiedrības veselības labā attaisno risku, kas varētu draudēt pacientam.

Kā uzsvērts tiesību doktrīnā, tad par sociāli derīgu mērḳi ir atzīstama personas dzīvība, veselība, īpašums, sabiedrības labklājỉba un dažādas citas sabiedriskās un valsts intereses. Turklāt par sociāli derīgu mērḳi tiek uzskatīta zinātniskā darbība, kas pati nav virzìta uz svarīgu interešu aizsardzību, bet veikta, lai paplašinātu zināšanas par pasauli. Piemēram, "jaunas vakcīnas injekciju, tikko apgūtas jaunas tehnoloǵijas aprobāciju, nule konstruētu lidaparātu izmēǵinājumu u. c.” [13]. Personas, kura piedalās pētnieciskajā procesā, tiesiskā aizsardzība ir līdzīga pacienta tiesību aizsardzībai. Tas ir pareizi, jo, piemēram, cilvēkiem paredzēto zāḷ izpētes process var notikt vienlaikus ar ārstniecības procesu.

Detalizēta kārtība personas, kura piedalās izpētes procesā, piesaistei, iegūstot personas vai tās pārstāvja informēto piekrišanu, paredzēta Ministru kabineta 2010. gada 23. marta noteikumos Nr. 280 "Noteikumi par zāḷu klīniskās izpētes un lietošanas novērojumu veikšanas kārtību, pētāmo zāḷu marḳēšanu un kārtību, kādā tiek vērtēta zāllu klīniskās izpētes atbilstība labas klīniskās prakses prasībām” [10]. Personai jāsaṇem 
Aldis Lieljuksis. Pacientu autonomijas krimināltiesiskā aizsardzība Latvijā:

vai nepieciešama jauna norma Krimināllikumā?

informācija par izpētes būtību, nozīmīgumu, sekām un risku. Viṇa rakstiski apliecina, ka brīvprātīgi piekrìt piedalīies klīniskajā izpētē, norādot laiku, un paraksta sponsora izstrādāto pētāmās personas informēto piekrišanu. Ja attiecīgā persona nespēj rakstīt, izṇēmuma gadỉjumā viņa var sniegt mutisku piekrišanu vismaz viena liecinieka klātbūtnē. Attiecībā uz nepilngadīgo ir nepieciešama arī vismaz viena vecāka piekrišana.

Ārstniecības persona ir tiesīga riskēt, ja vēlamo rezultātu nekad nevar sasniegt bez riska. Kā uzsvērts Rīgas Stradiṇa universitātes pētījumā:

\begin{abstract}
“.. vainas prezumpcija nenozīmē, ka ārstniecības persona ir vainojama ikreiz, kad pacientam veselības stāvoklis pasliktinās vai neuzlabojas tā, kā tika sagaidīts. Medicīna ir loti riskanta nozare, un tajā rezultāts ir atkarīgs no l,oti daudziem savstarpēji korelējošiem faktoriem, vispirms jau no iedzimtības, kā arī no pacienta vecuma, dzimuma, veselìbas stāvokḷa kopumā, pacienta organisma reakcijas uz atseviškiiem medicīnas tehnologijas komponentiem, pacienta līdzestības u. tml. Ši daudzu faktoru pastāvēšana un ietekme medicīnā uztur pastāvīgu risku, no kura nevar izvairīties. Risinot jautājumu par ārstniecības personu atbildību vispār, ne tikai civiltiesisko atbildību, jāatceras Hipokrāta princips: primum non nocere ("pirmkārt, - nekaitē"). Tomēr dažās medicīnas nozarēs risks ir pastāvīgi klātesošs, un robeža starp nekaitēšanu un risku, kas var būtiski palīdzēt pacientam, ir netverama" [17].
\end{abstract}

Latvijas pacientu tiesību doktrīnā tiek uzsvērts, ka

"nav vienotu uzskatu vai vadlīniju, kādā apmērā ir jādod informācija pacientam par riskiem, kas saistīti ar konkrētu procedūru. Svarīgi, ka pacients izprot un spēj izvērtēt riskus, kā arī labumu un neērtības, ko kāda darbība dod pašam pacientam” [22].

Klīniskos pētījumos risks ir augstāks, jo izmantojamās zāles vai tehnologijas vēl nav izpētìtas tādā līmenī, lai risks un sekas būtu pietiekami skaidri prognozējami, turklāt pacienta reakcija var būt atškiriīga. To apstiprina visai biedējošo iespējamo blakusparādību apraksts pat visparastāko bezrecepšu zāḷu lietošanas instrukcijās, piemēram, Coldrex Maxgrip Lemon zālēm, kas lietojamas saaukstēšanās vai gripas gadījumā, kā iespējamās blakusparādības ir minēta gan neizskaidrojama asiņošana, gan redzes zudums. Tiesību doktrīnā ir nostiprinājusies atziṇa, ka profesionālā riska veicēja, ārstniecības personas, labvēlīga iznākuma iespējai ir jābalstās uz profesionālo prasmi, pieredzi un jaunākajiem sasniegumiem zinātnē un tehnikā [14]. Šis apstāklis arī nosaka nepieciešamību ārstniecības personai patstāvīgi papildināt zināšanas tālākizglīiības pasākumos, lai uzturētu profesionālo kompetenci. Jāatzīmē, ka Latvijā nav zināms neviens gadījums, kad šì Krimināllikuma norma būtu praksē izmantota. Situācijās, kad jārīkojas operatīvi, sniedzot neatliekamo palīdzību, glābjot pacienta dzìvību vai veselību, anamnēze nav noskaidrojama vai eksistē citi nelabvēlīgi apstākḷi un informētā piekrišana nav iegūstama, ārstniecības personai ir jārīkojas profesionālā riska situācijā. Šādā gadỉjumā ārsts rīkojas atbilstoši Pacientu tiesību likuma 7. panta astotajai dal̦ai un lēmumu pieṇem ārstu konsīlijs. Savukārt atbilstoši Pacientu tiesību likuma 7. panta devìtajai daḷai k̦irurğiskās vai cita veida invazīvās iejaukšanās laikā ārstējošajam ārstam bez pacienta piekrišanas ir 
Aldis Lieljuksis. Pacientu autonomijas krimināltiesiskā aizsardzība Latvijā:

vai nepieciešama jauna norma Krimināllikumā?

tiesības veikt iepriekš neplānotu ārstēšanu, ja pacientam sniedzama neatliekamā medicīniskā palīdzība vai ja neveiktās ārstēšanas dēḷ radīsies nesalīdzināmi lielāks kaitējums vina veselïbai.

Krimināllikuma VI nodaḷā "Atbrīvošana no kriminālatbildības un soda” ir ietvertas normas, kas paredz, ka personu, kura izdarījusi kriminālpārkāpumu vai mazāk smagu noziegumu, prokurors var nosacìti atbrīvot no kriminālatbildības, savukārt tiesa var atbrīvot no soda izciešanas, ja persona piekritusi labprātīgi ārstēties no alkohola, narkotisko, psihotropo, toksisko vielu vai citas atkarības. Atbilstoši Krimināllikuma 58. ${ }^{1}$ panta piektajai dal̦ai un 59. panta ceturtajai dal̦ai sods izpildāms, ja persona tiesas noteiktajā laikā nav uzsākusi ārstēšanos vai pēc tam izvairijusies no ārstēšanās. Uz šādām personām nenoliedzami attiecas Pacientu tiesību likuma 6. panta pirmajā daḷa paredzētās tiesības dot informēto piekrišanu, kā arī ceturtajā daḷā garantētās tiesības atteikties no ārstniecībā izmantotās metodes, neatsakoties no ārstniecības kopumā.

Krimināllikuma VIII nodaḷā "Medicīniska rakstura piespiedu līdzekḷı" ietverts tiesiskais regulējums attiecībā uz personām, kas izdarījušas Krimināllikumā paredzētu noziedzīgu nodarijumu un sirgst ar psihiskiem traucējumiem vai ir atzìtas par nepieskaitāmām vai ierobežoti pieskaitāmām. Šādām personām tiesa var noteikt šādus medicīniskus piespiedu līdzekḷus: 1) ambulatoru ārstēšanu medicīnas iestādē; 2) ārstēšanu vispārēja tipa psihiatriskajā slimnīcā (nodaḷā); 3) ārstēšanu specializētā psihiatriskajā slimnīcā (nodaḷā) ar apsardzi; 4) ja persona pēc izdarītā nodarỉjuma rakstura un sava psihiskā stāvokḷa dēl nav bīstama sabiedrībai, tiesa var nodot to tuvinieku vai citu personu, kas veic slimnieku kopšanu, gādībā.

Jāatzīmē, ka pret šādu personu, kas ievietota ārstniecības iestādē, tāpat kā pret personu, kura ievietota ārstniecības iestādē bez viņas piekrišanas, pastāvot Ārstniecības likumā 69. ${ }^{1}$ panta 6. daḷas nosacījumiem, t. i., gadījumos, kad pastāv tieši draudi, ka pacients psihisku traucējumu dēḷ var nodarīt miesas bojājumus sev vai citām personām vai pacients izrāda vardarbību pret citām personām un ar mutisku pārliecināšanu nav izdevies pārtraukt apdraudējumu, psihiatriskajās ārstniecỉbas iestādēs ir tiesības izmantot šādus ierobežojošus līdzekḷus:

1) fizisku ierobežošanu, izmantojot fizisku spēku pacienta kustību ierobežošanai;

2) mehānisku ierobežošanu, pielietojot ierobežojošas saites vai siksnas;

3) medikamentu ievadišanu pacientam pret viṇa gribu;

4) ievietošanu novērošanas palātā.

Ierobežojošo līdzekli var piemērot tikai ārsts.

Ierobežojošo līdzekḷu piemērošanas kārtību nosaka Ministru kabineta 2016. gada 12. jūnija noteikumi Nr. 453 "Noteikumi par kārtību, kādā ierobežojami pacienti, un priekšmetiem, kurus aizliegts turēt psihiatriskajā ārstniecības iestādē". Atbilstoši noteikumu 5. punktam, uzsākot pacienta ierobežošanu, ārstējošais ārsts vai dežūrārsts pacientam mutiski izskaidro ierobežojošo līdzekḷu piemērošanas iemeslu. Savukārt atbilstoši noteikumu 12. punktam, ja pacientam kā ierobežojošu līdzekli piemēro medikamentu 
Aldis Lieljuksis. Pacientu autonomijas krimināltiesiskā aizsardzība Latvijā:

vai nepieciešama jauna norma Krimināllikumā?

ievadīšanu pret pacienta gribu, ārstējošais ārsts vai dežūrārsts pārskata pacientam iepriekš ordinēto medikamentozo terapiju. Ja nepieciešams, ārsts veic medikamentozās terapijas korekcijas un izdara par to ierakstu pacienta medicīniskajā dokumentācijā.

Krimināllikuma Sevišḳā daḷa. Saistībā ar pacientes gribas pārkāpšanu kriminālatbildība ir paredzēta Krimināllikuma 135. panta "Aborta nelikumīga izdarīšana" ceturtajā dạ̦ā, kur paredzēta kriminālatbildība par aborta izdarīšanu pret pacientes gribu vai ja aborta neațlauta izdarīšana izraisījusi grūtnieces nāvi vai citas smagas sekas. Sods ir brīvības atnemšana uz laiku no trim lïdz divpadsmit gadiem, atṇemot tiesības nodarboties ar ārstniecību uz laiku līdz 10 gadiem.

Grūtniecības pārtraukšanas tiesisko pamatu veido: Pacientu tiesību likums, Ārstniecības likums, Seksuālās un reproduktīvās veselības likums [3] un uz likuma pamata izdotie Ministru kabineta 2003. gada 28. oktobra noteikumi Nr. 590 "Grūtniecïbas pārtraukšanas organizatoriskā kārtība", kas nosaka ne tikai medicīniskos kritērijus, bet arī pasākumus pirms grūtniecības pārtraukšanas un vispārīgās prasības, kā arī speciālās prasības gadījumos, kad grūtniecība tiek pārtraukta medicīnisku indikāciju dēl vai kad iestājusies grūtniecība pēc izvarošanas un gadījumos, kad grūtniece nav sasniegusi 16 gadu vecumu.

Normatīvie akti paredz, ka abortu tiesiski var izdarīt tikai ārstniecības iestādē. Jāṇem vērā: lai nepieļautu tiesību aktos ietverto noteikumu pārkāpumu, vienlaikus ir jāvadās no visiem normatīvajiem aktiem, jo atseviškłi aspekti ir ietverti dažādos iepriekš minētajos tiesību aktos. Tā, piemēram, minēto Ministru kabineta noteikumu 6. punktā ir noteikts, kādos gadījumos aborts nav izdarāms dienas stacionārā. Savukārt Seksuālās un reproduktīvās veselības likuma 26. panta ceturtajā dal̦ā papildus paredzēts, ka pārtraukt grūtniecību medicīnisku indikāciju dēḷ vai gadījumā, kad tā iestājusies izvarošanas rezultātā, drīkst tikai ginekologs (dzemdību speciālists) stacionārā ārstniecības iestādē.

"Bez tiesiska pamata" ir pamatpazīme, kas ietverta Krimināllikuma normas pirmajā dạ̦ā. Pastāvot kaut vienam normatīvajos aktos noteiktam prasību pārkāpumam, ir pamats uzskatīt, ka ir pārkāpts aborta izdarīšanas tiesiskais pamats. Grūtniecības tiesiskas pārtraukšanas saturu laika aspektā atklāj Seksuālās un reproduktīvās veselības likuma VI nodaḷas "Grūtniecības pārtraukšana" normas, kā arī iepriekš minēto Ministru kabineta noteikumu otrais punkts. Normas nosaka, ka legāls aborts ir grūtniecības pārtraukšana pēc sievietes vēelěšanās līdz grūtniecības 12 . nedēḷai (11 nedēḷām 7 dienām) ārstniecības iestādē, kas izvērtēta ārstniecỉbas jomu regulējošajos normatīvajos aktos noteiktā kārtībā un atbilst obligātajām prasībām. Savukārt medicīnisks aborts ir grūtniecības pārtraukšana medicīnisku indikāciju dēl līdz grūtniecības 24 . nedēḷai (23 nedēl̦ām 7 dienām) vai, ja grūtniecība ir izvarošanas sekas, līdz grūtniecības 12. nedēlai (11 nedēḷām 7 dienām) ārstniecības iestādē, kas izvērtēta ārstniecības jomu regulējošajos normatīvajos aktos noteiktā kārtībā un atbilst obligātajām prasībām.

Normas ceturtajā daḷa paredzētais apstāklis "pret grūtnieces gribu" ir nenoliedzami saistìts ar normatīvajiem aktiem, kuros noteikta gribas noskaidrošana, fiksēšana un situācijas, kā rīkoties, ja personas gribu nav iespējams konstatēt. "Pret personas gribu" - tiesību 
doktrīnā par tādu tiek uzskatīta arī situācija, kad paciente nav bijusi informēta par priekšā stāvošo operāciju [15]. Mazāk smagu seku gadījumā, kad notikusi neaț̣auta aborta izdarīšana un nav iestājusies nāve vai citas smagas sekas, piemērojama normas pirmā vai otrā dalıa atkarībā no panta dạ̦ā paredzētajiem citiem apstākḷiem.

Ārstniecības personai ir jānemem vērā arī Seksuālās un reproduktīvās veselības likuma 25. panta trešās daḷas prasības, ka grūtniecības pārtraukšanu drīkst veikt ne agrāk kā 72 stundas pēc grūtniecības pārtraukšanas norīkojuma izsniegšanas, pirms tam atkārtoti informējot sievieti par grūtniecības pārtraukšanas gadïjumā iespējamiem sarežǵỉjumiem. Turklāt pēc 2019. gadā veiktajiem grozìjumiem likumā grūtniecei, kura vēlas mākslīgi pārtraukt grūtniecîbu, valsts nodrošina iespēju saṇemt konsultāciju pie gimenes ārsta vai cita speciālista (ārsta psihoterapeita, ginekologa vai citas ārstniecības personas), kurš ir apmācīts sniegt šādu konsultāciju. Atbilstoši minētā likuma 26. panta trešajai daļai grūtniecības pārtraukšana medicīnisku indikāciju dēḷ vai gadījumā, kad tā iestājusies izvarošanas rezultātā, piel̦aujama, ja ir ārstu konsîlija apstiprinājums un saṇemta sievietes rakstveida piekrišana.

Svarīga ir personas gribas fiksācijas precīza dokumentēšana. Jautājumā par informēto piekrišanu Ministru kabineta 2003. gada 28. oktobra noteikumu Nr. 590 "Grūtniecības pārtraukšanas organizatoriskā kārtība" [11] 6. punkts paredz, ka ārstējošais ārsts vai pacients var pieprasīt piekrišanas noformējumu rakstveida formā, kuru pacients apstiprina ar savu parakstu, norādot datumu un laiku. Laika fiksācija ir svarīga ne tikai no formālā viedokḷa, bet arī no pacienta brīvas gribas izvērtēšanas viedokḷa, pretenziju gadījumā noskaidrojot, vai persona ir laikus saṇēmusi informāciju un apliecinājums nav izteikts, personai jau atrodoties zāḷu ietekmē un pilnvērtīgi neizprotot piekrišanas saturu. Tātad - noskaidrojot arī to, vai nav pārkāptas Pacientu tiesību likumā noteiktās prasības par informētās piekrišanas savlaicīguma un brīvas gribas izpausmi. Saturiski grūtniece rakstiskā apliecinājumā norāda, ka saṇēmusi informāciju no ginekologa (dzemdību speciālista) par grūtniecības pārtraukšanas gaitu un iespējamiem sarežǵỉjumiem; izvēlējusies atsāpināšanas veidu un saṇēmusi informāciju no ārsta anesteziologa par iespējamiem atsāpināšanas procedūras sarežğijumiem; ginekologa (dzemdību speciālista) vai ǵimenes ārsta informāciju, kas pamatota uz konsīlija atzinuma par iespējamiem sarežğìjumiem, ja grūtniecība tiks saglabāta. Konsīilija atzinumu pievieno medicīniskajai dokumentācijai.

Ja persona ir jaunāka par 16 gadiem, Seksuālās un reproduktīvās veselības likuma 27. pantā noteiktas īpašas prasības, kuras jāievēro ārstniecības personām. Vispirms jāuzsver pienākums uzklausìt pacientu, veltot pienācīgu uzmanību personas uzskatiem, n,emot vērā viñas vecumu un brieduma pakāpi. Noteikts pienākums informēt grūtnieces vecākus vai aizbildni par grūtniecības iestāšanos un saṇemt vismaz viena vecāka vai aizbildṇa rakstisku piekrišanu pirms norīkojuma par grūtniecības pārtraukšanu pēc pacientes pašas vēlēšanās. Ja pacientei, kura ir jaunāka par 16 gadiem, radies strīds ar vecākiem vai aizbildni par grūtniecības saglabāšanu, grūtniecības pārtraukšanai nepieciešams bāriṇtiesas lēmums. 
Aldis Lieljuksis. Pacientu autonomijas krimināltiesiskā aizsardzība Latvijā:

vai nepieciešama jauna norma Krimināllikumā?

Kā starpinstitūciju sadarbības un līdztekus tiesiskais aspekts jāmin tas, ka izvarošanas gadījumā ir nepieciešama tiesībaizsardzības iestādes izsniegta izziṇa par izvarošanu. Šeit jāatzīmē, ka izziṇas izsniedzēja var būt Valsts policijas struktūrvienība, prokuratūra vai tiesa, proti, institūcija, kas veic nodarījuma izmeklēšanu vai iztiesāšanu.

Ministru kabineta 2003. gada 28. oktobra noteikumos Nr. 590 "Grūtniecības pārtraukšanas organizatoriskā kārtība" norādīts uz atšḳirīgām situācijām un konsīlija sastāvu gadījumos, kad sievietei ir iespējami vai radušies sarežğìjumi grūtniecības gaitā, un gadījumos, kad sievietei ir iespējami vai radušies aug̣̣a attīstības traucējumi. Pirmajā situācijā ārstu konsîlijā piedalās ginekologs (dzemdību speciālists), giimenes ārsts un attiecīgais speciālists - ambulatorā ārstniecības iestādē; vai ginekologs (dzemdību speciālists), ginekologiiskās nodạ̣as vadītājs un attiecīgais speciālists - stacionārā ārstniecības iestādē. Otrajā situācijā - ja sievietei iespējami vai radušies augḷa attīstības traucējumi - konsīliju organizē ārsts (genētiḳis). Šajā gadījumā konsīlijā piedalās ārsts (ǵenētikisis), ginekologs (dzemdību speciālists), kā arī ginekologs (dzemdību speciālists), kuram ir sertifikāts ultraskaṇas izmeklēšanā dzemdniecībā un ginekologiijā. Ja aborts veikts kḷūdainas diagnozes dẹl, tad jāuzskata, ka aborts veikts bez tiesiska pamata.

Kā redzams no normas ceturtās daḷas dispozīcijas, tad kvalificējošie apstākḷi ir aborta izdarī̌̌ana pret grūtnieces gribu vai neatḷauta aborta izdarīšanas sekas ir grūtnieces nāve vai citas smagas sekas. Smagas sekas ir ietvertas likuma Par Krimināllikuma spēkā stāšanās un piemērošanas kārtību 24. pantā: atbildība par Krimināllikumā paredzēto noziedzīgo nodarījumu, kas izraisījis smagas sekas, iestājas, ja noziedzīgā nodarījuma rezultātā izraisīta cilvēka nāve, smagi miesas bojājumi vismaz vienai personai, vidēji smagi miesas bojājumi vairākām personām, mantisks zaudējums, lielāks par 50 minimālajām mēnešalgām, kā arī radīts cits smags kaitējums ar likumu aizsargātām interesēm.

Krimināllikuma 138. pantā paredzēta atbildība ārstniecības personai par profesionālo pienākumu nepildīšanu vai nolaidīgu pildīšanu. Atbildība iestājas, ja atbilstoši normas pirmās dạ̦as dispozịcijai profesionālo pienākumu pildīšanas laikā personai nodarīti vidēja smaguma miesas bojājumi, atbilstoši normas otrajai dal̦ai personai nodarīti smagi vai vidēji smagi miesas bojājumi vai atbilstoši normas otrajai daḷai pacients inficēts ar cilvēka imūndeficīta vīrusu, vai B vai $C$ hepatīta vīrusu, vai bijis par iemeslu cietušā nāvei. Jāatzīmē, ka kopš 2018. gada 1. janvāra par miesas bojājumiem tiek uzskatìti ne tikai cilvēka organisma audu, orgānu vai sistēmu anatomiski bojājumi vai funkcionāli traucējumi, kas radušies mehānisku, termisku, elektrisku, akustisku, radiācijas, ķīmisku, biologísku vai citu iedarbību rezultātā. Miesas bojājumiem pielīdzināmi arī psihiski traucējumi vai traumas, kas radušās psihisku vai iepriekš minēto iedarbību rezultātā.

Sods par normas pirmajā daḷā paredzēto rīcību (darbỉbu vai bezdarbỉbu) ir brīiības atṇemšana uz laiku līdz vienam gadam vai îslaicīga brīvības atṇemšana (no 15 dienām lìdz trim mēnešiem) vai piespiedu darbs (kā pamatsods no 40 līdz 280 stundām vai kā papildsods no 40 līdz 100 stundām) vai naudas sods (no trim līdz tūkstoš minimālajām 
mēnešalgām) ${ }^{1}$. Ja iestājas otrajā daḷā paredzētās sekas, sods ir brīivibas atnememšana līdz pieciem gadiem, ìslaicīga brīvības atṇemšana vai piespiedu darbs, vai naudas sods (no desmit līdz diviem tūkstošiem noteiktajām minimālajām mēnešalgām).

Normas kontekstā jāpievēršas ārstniecỉbas personas kā Krimināllikuma 138. panta nodarijuma subjekta darbības regulācijai, jo norma paredz atbildību par ārstniecības personas profesionālo pienākumu nepildī̌sanu vai nolaidīgu pildī̌̌anu. Ārstniecības personas atbilstoši Ārstniecības likuma 1. panta 2. punktam ir personas, kam ir medicīniskā izglìtība un kas nodarbojas ar ārstniecību. Ārstniecības personas profesionālie pienākumi veselības aprūpē var būt saistīti ar tādu pakalpojumu sniegšanu, kas nav tieši saistīti ar kādas slimības ārstēšanu vai profilaksi, kā, piemēram, neatliekamās medicīniskās palīdzības sniegšana traumas gadījumā, ko veic speciāli sagatavotas un ekipētas ārstniecības personas. Cilvēkiem var rasties nepieciešamība veikt dažādus laboratoriskus izmeklējumus profilaktiskos nolūkos, zobu protezēšanu, estētiski ķirurgískas operācijas, redzes korekciju, saṇemt kosmetologiskus pakalpojumus u. c. Tiesībsargājošo iestāžu darbiniekiem ikdienā jāveic likumpārkāpumā iesaistīto personu pārbaude ārstniecības iestādē saistībā ar narkotisko, psihotropo vai toksisko vielu lietošanu. Pirms uzsākt intensīvas sportiskas aktivitātes, vēlams saṇemt sporta ārsta rekomendācijas.

Iepriekš minētajos piemēros ir redzams visai plašais veselības aprūpes pakalpojumu klāsts, kuru realizācijas gaitā nav izslēgts, ka iestājas izskatāmajā normā paredzētās sekas, kuru cēlonis ir ārstniecības personas profesionālo pienākumu nepildīšana vai nolaidīga pildīšana. Ārstniecības personu un ārstniecības atbalsta personu (nav normas speciālais subjekts) klasifikators ir ieviests Ministru kabineta noteikumos Nr. 317 [9]. Atbilstoši šiem noteikumiem, piemēram, kosmetologs ir ārsta papildspecialitāte, savukārt solārija darbinieks ir ārstniecības atbalsta persona. Nepieciešams minēt arī situācijas, kad ārstniecības persona vienlaikus ar ārstniecības procesu veic arī klīniskos pētījumus.

Informētās piekrišanas sakarā ārstniecības personas atbildība var iestāties, piemērojot šo normu, ja ārstniecības persona situācijās, kā tas ir paredzēts iepriekš izskatìtajās Pacientu tiesību likuma normās, savu pienākumu nav vispār izpildījusi vai izpildījusi nolaidīgi un ir iestājušās kādas no normā paredzētajām sekām. Šāda rīcība vērtējama kā bezdarbība, jo persona nav veikusi ar Pacientu tiesību likumu uzliktos pienākumus. Nenoliedzami, ka informētās piekrišanas aspekts ir būtisks faktiskais apstāklis, jo ārstniecība bez informētās piekrišanas nav tiesiska, tāpēc ikvienā situācijā jāvērtē, kad pacientam nodarìts kaitējums, par kuru paredzēta kriminālatbildība. Kā jau iepriekš minēts, krimināltiesību aspektā nav neviena kriminālprocesa, kur šāda situācija tiktu iztiesāta, līdz ar to iespējams runāt vien teorētiski.

1 Naudas soda apmērs ir noteikts Krimināllikuma 41. pantā, un tas ir atkarīgs no nodarījuma smaguma. No 2021. gada 1. janvāra Latvijas Republikā minimālā mēnešalga ir 500 eiro. 
Modelējot iespējamās situācijas, var secināt, ka iespējami vairāki faktiskie apstākḷi.

1. Kḷūdas dēḷ notikusi ārstniecība nepareizajam pacientam.

2. Ārstniecība notikusi ar pacienta piekrišanu, taču kḷūdas dēḷ sajaukti orgāni vai notikusi iejaukšanās, ievadot neparedzētus mediciniskos preparātus.

3. Ārstniecības procesā ārstniecības persona bez pietiekama pamata veikusi pacienta piekrišanā neparedzētas (neatrunātas) darbības.

4. Ārstniecības persona veikusi ārstniecību, dodot personai acīmredzami nepamatotus solïjumus par pozitīvu rezultātu.

5. Ārstniecība veikta ar pacienta piekrišanu, taču bez faktiskas nepieciešamības.

6. Persona ievietota pret tās gribu un prettiesiski psihiatriskajā ārstniecības iestādē.

7. Pacients nav bijis informēts par riskiem, kas iestājušies ārstniecības procesā, radot Krimināllikuma 138. pantā paredzētās sekas.

Vainas forma attiecībā pret sekām var būt tikai neuzmanība, t. i., atbilstoši Krimināllikuma 10. pantam nodarījums izdarīts noziedzīgas pašpaḷāiības dẹl (ja persona ir paredzējusi savas darbības vai bezdarbības kaitīgo seku iestāšanās iespēju, tomēr vieglprātīgi paḷāvusies, ka tās varēs novērst) vai noziedzīgas nevērības dēḷ (ja persona nav paredzējusi savas darbības vai bezdarbības kaitīgo seku iestāšanās iespēju, kaut gan pēc nodarījuma konkrētajiem apstākḷiem tai vajadzēja un tā varēja minētās kaitīgās sekas paredzēt).

Ja ārstniecības persona rīkojusies ar nodomu nodarìt kaitējumu pacienta dzīvībai vai veselībai, tad nodarỉjumu kvalificē kā nodarījumu pret personas dzìvību vai veselību. Jāpiebilst, ka tādi nodarījumi Latvijā nav fiksēti.

Komplicēti ir gadỉjumi, kad ārstniecība jāveic psihiatriskajās klīnikās garīgi slimām personām. Situāciju regulē Ārstniecības likuma normas un uz likuma pamata izdotie Ministru kabineta 2016. gada 12. jūnija noteikumi Nr. 453 "Noteikumi par kārtību, kādā ierobežojami pacienti, un priekšmetiem, kurus aizliegts turēt psihiatriskajā ārstniecības iestādē" [8]. Normatīvais regulējums ir atšḳirīgs, ja persona brīvprātīgi vēlas saṇemt palīdzību, turklāt ambulatorajai un palīdzībai dzīvesvietā ir priekšroka pret stacionāro palīdzību. Tikai tad, ja slimnieka veselības stāvokḷa dēl tas nav iespējams, palīdzība tiek sniegta stacionārā. Stacionēšanai nepieciešama pacienta rakstveida piekrišana, kas tiek pievienota medicīniskajiem dokumentiem. Pret šādām personām nav ațauts piemērot ierobežojošos līdzekḷus. Ja pret personu, kura brīvprātīgi iestājusies stacionārā, tomēr nāktos piemērot ierobežojošus līdzekḷus, ir jāmaina personai juridiskais statuss un iestājas tiesas kontrole.

Personām, kuras stacionētas ārstniecības iestādē bez viṇu piekrišanas, un pacientiem, kuriem ārstniecība psihiatriskajā ārstniecības iestādē noteikta kā medicīniska rakstura piespiedu līdzeklis kriminālprocesā, ir Pacientu tiesību likumā garantētās tiesības, kas expresis verbis pateikts Ārstniecības likuma 69. ${ }^{1}$ panta pirmās dalıas pirmajā punktā. Par šìm tiesībām ārstniecības persona nekavējoties informē pacientu vinnam saprotamā formā, ñemot vērā pacienta vecumu, briedumu un pieredzi. Ja nepieciešams, ārstniecības persona minēto informāciju sniedz atkārtoti. 
Nelikumīga ievietošana psihiatriskajā slimnīcā. Kriminālatbildība par apzināti nelikumīgu ievietošanu psihiatriskajā slimnīcā paredzēta Krimināllikuma 155. pantā. Atškịīibā no iepriekš analizētajām Krimināllikuma normām šī nodarījuma objekts ir personas neaizskaramība un personiskā brīvība, par ko liecina arī Krimināllikuma XV nodal̦as nosaukums "Noziedzīgi nodarījumi pret personas brīvību, godu un cien̦u". Sods ir îslaicīga brīvības atṇemšana, piespiedu darbs vai naudas sods (no vienas līdz simts noteiktajām minimālajām mēnešalgām). Nelikumīga personas ievietošana psihiatriskajā slimnīcā no objektīvās puses izpaužas kā noteiktās kārtības pārkāpšana.

Psihiatrisko palīdzību bez pacienta piekrišanas sniedz Ārstniecības likuma 68. pantā noteiktos gadījumos un kārtībā, ja pacients

1) ir draudējis vai draud, centies vai cenšas nodarìt sev vai citai personai miesas bojājumus vai ir izturējies vai izturas varmācīgi pret citām personām un ārstniecības persona konstatē, ka pacientam ir psihiskās veselības traucējumi, kuru iespējamās sekas varētu būt nopietni miesas bojājumi pacientam pašam vai citai personai;

2) ir izrādījis vai izrāda nespēju rūpēties par sevi vai savā aizbildnībā esošām personām un ārstniecības persona konstatē, ka pacientam ir psihiskās veselības traucējumi, kuru iespējamās sekas varētu būt nenovēršama un nopietna personas veselības pasliktināšanās.

Sniedzot psihiatrisko palīdzību bez pacienta piekrišanas iepriekš minētajos gadījumos, pacientam, ja tas ir iespējams, izskaidro šādas psihiatriskās palīdzības sniegšanas nepieciešamību. Pacientam ir tiesības saṇemt informāciju par savām tiesībām un pienākumiem. Pacientu izmeklē un lēmumu par pacienta stacionēšanas nepieciešamību un palīdzības sniegšanu psihiatriskās ārstniecības iestādē bez viṇa piekrišanas vai tās pārtraukšanu pieṇem ārstu konsīlijs 72 stundu laikā. Psihiatru konsīlijs nekavējoties paziṇo savu lēmumu pacientam. Ja psihiatru konsīlijs pien̦em lēmumu par psihiatriskās palīdzības sniegšanu, par to informē pacienta likumisko pārstāvi. Ja pacientam nav likumiskā pārstāvja, par pieṇemto lēmumu psihiatru konsīlijs informē pacienta laulāto vai vienu no pacienta tuvākajiem radiniekiem (vecākus, pilngadīgos bērnus, brāḷus vai māsas), vai pēc pacienta lūguma citu personu. Lemjot par personu, kurai paziṇojams lēmums par psihiatriskās palīdzības sniegšanu, pēc iespējas ṇem vērā pacienta viedokli.

Ja psihiatru konsīlijs ir pieṇēmis lēmumu par psihiatriskās palīdzības sniegšanu, psihiatriskās ārstniecības iestāde par to rakstveidā 24 stundu laikā informē rajona (pilsētas) tiesu (atbilstoši psihiatriskās ārstniecības iestādes atrašanās vietai), nosūtot tai lēmuma norakstu un psihiatriskās ārstniecības iestādes rīcībā esošo dokumentu kopijas, kas pamato pacienta ievietošanu psihiatriskās ārstniecības iestādē, kā arī sniedz informāciju par pacienta pārstāvi, ja tāds ir. Ja nav pacienta pārstāvja, tad tiek uzaicināts zvērināts advokāts un sēdē piedalās pacients (ja to pieḷauj viṇa veselības stāvoklis) un prokurors. Slēgta tiesas sēde notiek ārstniecības iestādes telpās, un tiesneša lēmums nav pārsūdzams. 
Aldis Lieljuksis. Pacientu autonomijas krimināltiesiskā aizsardzība Latvijā:

vai nepieciešama jauna norma Krimināllikumā?

Nodarījuma subjekts ir ārstniecības persona, bet gadỉjumos, ja tiesnesis pieņem apzināti nelikumīgu lēmumu par personas ievietošanu bez pietiekama pamata psihiatriskās ārstniecības iestādē, viņš saucams pie kriminālatbildības pēc Krimināllikuma 291. panta "Nelikumīga sprieduma un lēmuma taisišsana". Nodarījuma subjektīvā puse izpaužas kā tiešs nodoms. Nodarījuma sastāvs pēc uzbūves ir formāls un pabeigts ar personas ievietošanas brīdi psihiatriskajā klīnikā.

\section{Secinājumi}

1. Tikai Krimināllikuma 135. pantā expresis verbis paredzēta atbildība par aborta izdarī̌sanu pret grūtnieces gribu.

2. Tiesu nolēmumos krimināllietās pacientu informētās piekrišanas aspekts netiek vērtēts.

3. Situācijās, kad notikusi prettiesiska ārstniecība bez informētās piekrišanas un kad tādai bija jābūt, atbildība pēc Krimināllikuma 138. panta iestātos vienīgi tad, ja sekas būtu vismaz vidēji smagi miesas bojājumi.

4. Ir nepieciešams papildus veikt gan Latvijas un citu valstu praksi informētās piekrišanas aspektā, gan arī citu valstu tiesiskā regulējuma un tiesu prakses izpēti, pirms ieteikt paredzēt Krimināllikumā atbildību par ārstniecību bez informētās piekrišanas, kā tas ir noteikts Polijas, Portugāles un Lihtenšteinas krimināllikumos.

\section{Criminal Law Protection of Patient Autonomy in Latvia - a Need for a New Regulation in the Criminal Law}

\section{Abstract}

The article is a follow-up to the study on the protection of patients' rights under the criminal law. The article examines the provisions of the Criminal Law which legislates liability of medical practitioners for medical treatment without the patient's consent. Only Section 135 of the Criminal Law 'expresis verbis' provides for liability for abortion against the will of a pregnant woman. In other cases, liability may only arise in cases where at least moderate bodily injury has been caused during medical treatment. Court judgements do not address the issue of the informed consent, consequently, the factual situation is unclear. It should be noted that the legal framework differs from such European countries as Poland, Portugal and Liechtenstein, where criminal liability is imposed not only for the harm caused to the patient in healthcare, but also for treatment without the patient's 
Aldis Lieljuksis. Pacientu autonomijas krimināltiesiskā aizsardzība Latvijā:

vai nepieciešama jauna norma Krimināllikumā?

consent in situations where it was necessary because the fundamental rights have been unlawfully infringed.

The author considers that the research should be continued by identifying experience of other countries and the actual situation prior to putting forward a recommendation to impose criminal liability under the Criminal Law.

Keywords: Constitution, Criminal Law, informed consent.

\section{Avoti un literatūra}

\section{Tiesību avoti}

1. Latvijas Republikas Satversme: Latvijas valsts likums: pieṇemta 15.02.1922. un stājusies spēkā 07.11.1922. Latvijas Vēstnesis. 43, 01.07.1993.

2. Pacientu tiesību likums: Latvijas Republikas likums: pieṇemts 17.12.2009. un stājies spēkā 01.03.2010. Latvijas Vēstnesis. 205(4191), 30.12.2009.

3. Seksuāās un reproduktīvās veselības likums: Latvijas Republikas likums: pieñemts 31.01.2002. un stājies spēkā 01.07.2002. Latvijas Vēstnesis. 27, 19.02.2002.

4. Krimināllikums: Latvijas Republikas likums: pieṇemts 17.06.1998. un stājies spēkā 01.04.1999. Latvijas Vèstnesis. 199/200(1260/1261), 08.07.1998.

5. Ārstniecības likums: Latvijas Republikas likums: pieṇemts 12.06.1997. un stājies spēkā 01.10.1997. Latvijas Vēstnesis. 167/168, 01.07.1997.

6. Farmācijas likums: Latvijas Republikas likums: pieṇemts 10.04.1997. un stājies spēkā 08.05.1997. Latvijas Vēstnesis. 103, 21.04.1997.

7. Mincs, P., Lauva, J., sast. 1938. Sodu likums ar komentāriem. Rīga: Valsts tipogrāfija, 28.

8. Noteikumi par kārtību, kādā ierobežojami pacienti, un priekšmetiem, kurus aizliegts turēt psihiatriskajā ārstniecības iestādē: Latvijas Republikas Ministru kabineta noteikumi Nr. 453: pieñemti 12.06.2016. Latvijas Vêstnesis. 134, 14.07.2016.

9. Ārstniecības personu un ārstniecības atbalsta personu reğistra izveides, papildināšanas un uzturēšanas kārtība: Latvijas Republikas Ministru kabineta noteikumi Nr. 317: pieṇemti 24.05.2016. Latvijas Vēstnesis. 102, 27.05.2016.

10. Noteikumi par zāḷu klīniskās izpētes un lietošanas novērojumu veikšanas kārtību, pētāmo zāḷ marḳēšanu un kārtību, kādā tiek vērtēta zāḷu klīniskās izpētes atbilstība labas klīniskās prakses prasībām: Latvijas Republikas Ministru kabineta noteikumi Nr. 280: pieṇemti 23.03.2010. Latvijas Vëstnesis. 51/52, 31.03.2010.

11. Grūtniecības pārtraukšanas organizatoriskā kārtība: Latvijas Republikas Ministru kabineta noteikumi Nr. 590: pieñemti 28.10.2003. Latvijas Vēstnesis. 153, 31.10.2003.

12. Par kriminālsoda politikas koncepciju: Latvijas Republikas Ministru kabineta rīkojums Nr. 6. Latvijas Vēstnesis. 6, 13.01.2009.

\section{Literatūra}

13. Judins, A. 2006. Apstāklli, kas izslēdz kriminālatbildību. Rīga: Biznesa augstskola Turība, 192.

14. Krastiņš, U., Liholaja, V. 2015. Krimināllikuma komentāri. Pirmā daḷa (I-VIII ${ }^{I}$ nodaḷa). Rīga: Tiesu namu ağentūra, 320.

15. Krastinšs, U., Liholaja, V. (2016). Krimināllikuma kometāri. Rīga: Tiesu namu ag̉entūra, 320. 
Aldis Lieljuksis. Pacientu autonomijas krimināltiesiskā aizsardzība Latvijā: vai nepieciešama jauna norma Krimināllikumā?

16. Krastinš̌, U. 2010. Krimināllikumam 10 gadi: tapšana, attīstība un perspektīva. Juridiskā Zinätne. Nr. 1, 7., 8. lpp. Iegūts no: https://www.journaloftheuniversityoflatvialaw.lu.lv/fileadmin/user_upload/lu_portal/projekti/journaloftheuniversityoflatvialaw/No1/U_Krastins.pdf [sk. 25.11.2020.].

17. Liepiṇš, A., Vētra, J. Transformācijas process ārstniecības personu civiltiesiskās atbildības regulējumā. RSU Zinātniskie raksti. Iegūts no: https://www.rsu.lv/zinatniskie-raksti/transformacijasprocess-arstniecibas-personu-civiltiesiskas-atbildibas [sk. 29.11.2020.].

18. Mazure, L. 18.08.2020. Pārmērīgas ietekmes civiltiesiskās sekas pacienta gribas izteikumā. Jurista Vārds. Nr. 33.

19. Mazure, L. 2011. Pacienta griba un tās civiltiesiskā aizsardzība: promocijas darbs. Rìga: Latvijas Universitāte, 9. Iegūts no: https://dspace.lu.lv/dspace/handle/7/5100 [sk. 25.11.2020.].

20. Mincs, P. 2005. Krimināltiesības. Sevišķā daḷa. Ar V. Liholajas komentāriem. Rìga: Tiesu namu aǵentūra, 143.

21. Slokenberga, S., zin. red., 2015. Medicinnas tiesības. Rīga: Tiesu namu aǵentūra, 294.

22. Slokenberga, S., zin. red., 2019. Pacientu tiesību likuma komentāri. Latvijas Vēstnesis.

23. Vilks, A. 2013. Criminal policy: analysis of discourse and perspectives of developments. Rìga, 23.

24. World Health Organization. Constitution of the World Health Organization. Iegüts no: https:// www.who.int/governance/eb/who_constitution_en.pdf [sk. 27.11.2020.].

\section{Tiesu prakse}

25. Zemgales apgabaltiesas 2016. gada 26. oktobra spriedums lietā Nr. KA06-136-16, Krimināllieta Nr. 12390000512. Iegūts no: https://manas.tiesas.lv/eTiesasMvc/lv/nolemumi

26. Austākā tiesa. Tiesu prakse morālā kaitējuma atlīdzināšana civillietās un tiesu prakse morālā kaitējuma apmēra noteikšanā saistībā ar prasītājam nodarīto tiesību aizskārumu, miesas bojājumiem vai tuvinieku bojāeju (tiesu prakse 2011-2016). Iegūts no: http://www.at.gov.lv/lv/tiesuprakse/tiesu-prakses-apkopojumi/civiltiesibas [sk. 29.11.2020.]. 